础架

\title{
空気および液柱䁌りを有する流体䖝路内の週渡現象*
}

橋本强二** 今枝泣:夫** 長山 展 **

\section{Transients of Fluid Lines Containing Air Pocket or Liquid Column}

\author{
Kyoji Hashimoto, Masao Imaeda, Akira Osayama
}

This paper deals with transients following the rapid opening of a valve on the upstream sides of fluid lines containing air pocket or liquid column.

Experiments using test pipelines were carried out for the parameter variations in various elements. A theoretical calculation was first performed by applying Runge-Kutta-Gill-methods for the basic equations of lumped-element representation, and then, the pressure surge due to collision of a liquid column was calculated.

The principal points obtained are summarized as follows:

(1) There is a possibility that the pressure surge for an open system with small orifice-pipe cross sectional area ratio $A_{R}$ is greater than that of a confined system.

(2) Effects such as those of $A_{R}$, mass of liquid column and gradient of a pipeline on pressure surge were clarified.

(3) Methods for the approximate calculation of the pressure surge are effective for predicting the transients of fluid lines containing air pocket or liquid column.

\section{1. 緒 言}

管路系の過渡特性に関する研究は，系の解析および 楱成的見地から非常に重要であり，現在までに数多く なされてきていろか，管路内が液体および気体で满た されている単相流れを対象とした例が多く，液体管路 内に空気溜りがある系とか気体管路内に波柱溜りが存 在する系などを対象とした研究例は比较的少ないよう である.

星ら”はポンプ起動の際に送水管中を流れ始めた水 流が末端にある半開の并に達する際に生ずる水整につ いて解析し, Streeterら ${ }^{2)}$ ，北川ら 液体管路内の空洞の存在により生ずるサージ圧が通常 より大きくなるととを指摘している。 また北川は浫

\footnotetext{
* 昭和60年 3 月 28 日 原稿受付

** 徳島大学工学部
}

洞の存在に伴うサージ圧力を解析し，その結果に基う きサージ圧を程和する方法を提案している，さらに首 $5^{6)}$ (液体管路内の停留空洞分週渡時の流速変動に及

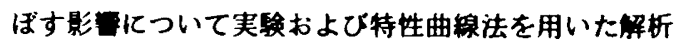

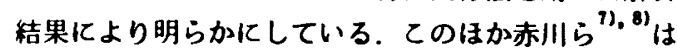
気はう流朽よびスラグ流を対象として下流端にある弁 の急閉制に伴う衙撃現象について解明している. 以上の液体管路内に空気燃りがある管路系の週渡現 象に関する諸研究においては，法柱か下流位雷にある 较り抵抗部に衙突する祭に生ずるサージ压力について 考察した研究例は，星ら“による図式解法を用いた解 析例以外にはほとんどなく，また気体管路内に洨柱溜 りが存在する系伅ついての検討例もはとんど見当たら ないようである.

そこで本研究では，液体管路内の下流位置に空気溜 りがある系および気体管路内に液柱溜りが存在する系 を統一的に取扱い，上流側の并の急開に伴い洨柱が下 


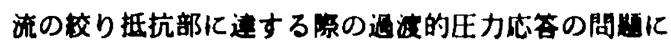

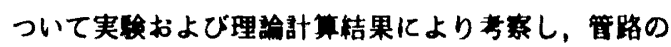
パラメータ変化がサージ田力に及ばす影田について明

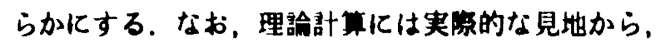

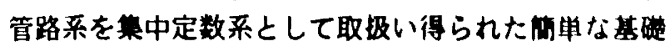
式とサージ厌の計算式を用い，得られた結果を实矣結 果と比校し，その有奻性を梌討する。

なお，乙の盾の問题は大形油圧管路および暖房用㟟 気谕送管路に㧍いて生ずる。

\section{2. 主な记号}

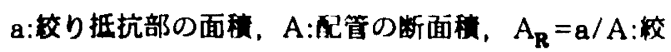

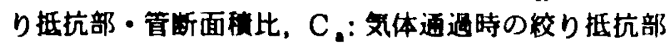
の流是係数， $\mathrm{C}_{\mathrm{w}}$ : 洨体通過時の较り抵抗部の流量係

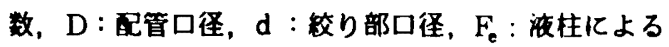
動摩撩力, $\mathrm{g}$ : 重力の加速度, $\mathrm{m}$ : 波柱の質量, $\mathrm{n}$ : ポリトロープ指数， $\mathrm{P}_{2}$ : 絞り部出口の圧力 (本研究で

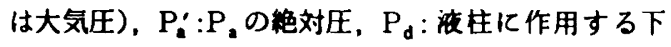
流側圧力， $\mathrm{P}_{\mathrm{u}}$ : 液柱仁作用する上流側圧力, $\mathrm{P}_{\mathbf{M}}$ : 液柱 哣突により生ずる最大上昇圧力，P.p：液柱が较り部 亿连する直前 $\left(t=t_{c}^{-}\right)$時に较り部に作用する圧力, $P_{a p}^{\prime}$ $: P_{\text {ap }}$ の絶対圧, $P_{s}$ : 供給圧, $Q_{2}$ : 较り部を通万気

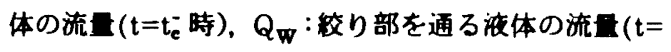
$\mathrm{t}_{\mathrm{e}}^{+}$時), $\mathrm{t}$ : 時間, $\Delta \mathrm{t}$ : 微小計算時間間隔, $\mathrm{V}_{\mathrm{w}}$ : 液柱 の移動速度， $\overline{\mathrm{V}}_{\mathrm{w}}$ : 液柱の平均移動速度， $\forall:$ 空気溜 りの容稓， $\forall_{0}$ : 空気溜りの初期容積， $\alpha$ : 洨体中の音 速, $\rho_{\mathrm{a}}:$ 気体の密度, $\rho_{\mathrm{w}}$ : 波体の密度, $\theta$ : 酉管の 烦斜角， $\epsilon$ : 㚝正係数。

\section{3. 解析モテルと計算法}

\section{1 争析モテル}

解析モデルとしてFig.1(a)に示す液体管路の下流位 置に空気溜りが存在する系およびFig.1(b)に示す気体 管路の途中に液柱が滞留している系を考える．Fig.1 (a), (b)㲸示す系において，上流側の并を急開すると液 柱が駆動し，下流位置にある絞り抵抗部に達する際に は通過流体の密度の相倳に基づく流量变化により大き なサージ王力が発生する可能性があり，てのようなサ 一ジ圧の予知は管路の安全性の面から非常に重要であ ろ.なお，Fig.1(a)に示す系と等価な事例としては， 接続配管の変更等の後に管路内に油や水などの液体を 急速に満たす場合などが考えられ，Fig.1(b)に示す系 は，工場および施設暖房用蒸気輸送管路において省工 ネルギーの锣点から蒸気の流量制御を行う際にみられ その他, 飲料製造プラント配管内の洗浄行程において るこの系と等価な状態が存在する場合がある.

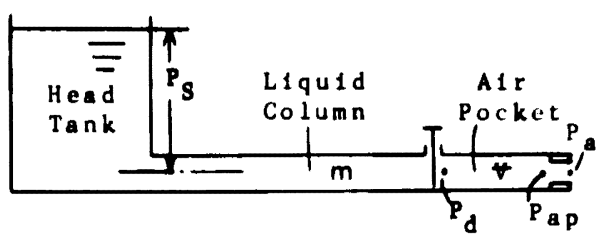

Fig. 1 (a) System with air pocket

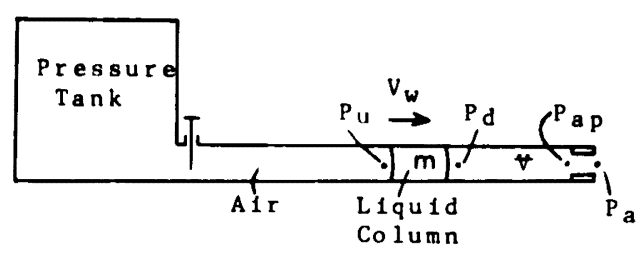

Fig. 1 (b) System with liquid column

\section{2 压力上年仕の旪策法}

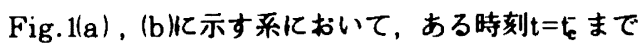
は気体が流出していたとすると，絞り抵抗部を通る気 体の流昷は式(1)で表される.

$$
\begin{aligned}
& Q_{a}=C_{\varepsilon} \varepsilon a \sqrt{2\left(P_{A D}-P_{a}\right) / \rho_{a}} \\
& \text { ここで, } \varepsilon=\sqrt{\frac{\kappa}{\kappa-1}\left(\left(\mathrm{P}_{\mathrm{a}}^{\prime} / \mathrm{P}_{\mathrm{ap}}^{\prime}\right)^{\frac{2}{\kappa}}-\left(\mathrm{P}_{\mathrm{a}}^{\prime} / \mathrm{P}_{\mathrm{ap}}^{\prime}\right)^{\frac{\kappa+1}{\kappa}}\right)}
\end{aligned}
$$

$\overline{/\left(1-P_{a}^{\prime} / P_{a p}^{\prime}\right)}, \kappa=$ 比整の比であり,$\left(P_{a p}^{\prime}-P_{a}^{\prime}\right) / P_{a p}^{\prime}$ $<0.02$ のときは $\varepsilon \fallingdotseq 1$ となり，非代綰性流体の場合と 同様な取扱いとなる。

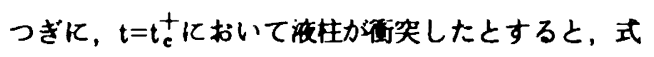
(2)が成立する.

$$
Q_{w}=C_{w} a \sqrt{2\left(P_{M}-P_{2}\right) / p_{w}}
$$

一方，液柱街突の際に生ずる圧力上昇值を求める基 礎式は次式(3)で表される。

$$
\mathrm{P}_{\mathrm{M}}-\mathrm{P}_{\mathrm{ap}}=\rho_{\mathrm{W}} \alpha\left(\mathrm{Q},-\mathrm{Q}_{\mathrm{w}}\right) / \mathrm{a}
$$

式(1)，(2)を式(3)に代入し， $P_{N}$ にいて解くと，最 大圧力上昇値の計算式が次のように求められる。（本 研究では絞り出口は大気に開放されているとする）

$\mathrm{P}_{\mathrm{M}}=\mathrm{P}_{\mathrm{ap}}+\rho_{\mathrm{W}} \alpha \mathrm{Q}_{\mathrm{a}}\left[1+\mathrm{BR}^{2}\left(1-\sqrt{1+\frac{2 \mathrm{~B}+1}{\mathrm{~B}^{2} \mathrm{R}^{2}}}\right)\right] / \mathrm{a}$ (4)

ここで, $\mathrm{B}=\alpha \rho_{\mathrm{w}} \mathrm{Q}_{\mathrm{a}} / 2 \mathrm{aP} \mathrm{ap}, \mathrm{R}=\left(\mathrm{C}_{\mathrm{w}} / \mathrm{C}_{\mathrm{a}} \varepsilon\right)$

$\sqrt{\rho_{\mathrm{a}} / \rho_{\mathrm{w}}}$ であろ.

さて，式(4)により最大圧力上昇値 $\mathrm{P}_{\mathrm{M}}$ を計算するた めには， $\mathrm{t}=\mathrm{t}_{\mathrm{c}}$ において较り抵抗部て作用する圧力 $\mathrm{P}$ ap 


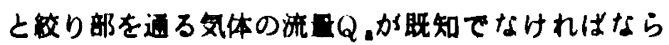
ない，このため，波柱の移助に伴う较り部直前位目で

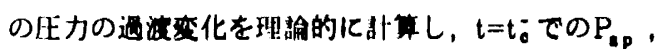
Q.を求めることにする.Fig.1(a)，(b)沉示す系に打い ては，洨柱の移㴞とともに波体と匃体の境界か時々効

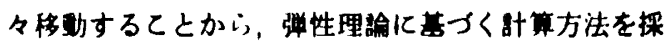

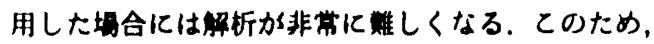
本研究では央际的な見地にたち，管路系を集中定数系

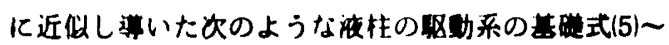
(7)を使用し、ルンゲクッタギル法により遇没影真を行

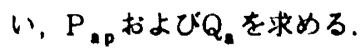

$$
\begin{aligned}
& m \frac{d V_{w}}{d t}=A\left(P_{u}-P_{d}\right)-F_{e}-m g \sin \theta \\
& \frac{d \forall}{d t}=-A V_{w} \\
& \frac{d P_{d}}{d t}=\frac{-n R T_{d}}{\forall} G_{0}+\frac{n P_{d} A}{\forall} V_{w}
\end{aligned}
$$

ここで, 式(5)/ておいて $F_{e}=m_{f V}\left|V_{w}\right| / 2 D$, 式(7) においてR=ガス定数， $T_{a}=$ 空気の温度， $G_{0}=$ 絞り部 を通る気体の質量流量である。なお，Fig.1la）に示す 系の埸合，液柱質量 $\mathrm{m}$ は洨柱の移䡃化伴い時々刻々変

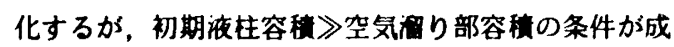
立する場合には，洨柱の速勒方程式(5)中の $\mathrm{m} \fallingdotseq$ 初期流 柱質量とおいて計算してもさしつかえないと考えられ 3.

\section{4. 実 検}

\section{1 做体管路の下流位是に空気䅦りがある系}

Fig.2 は液体管路の下流位国に空気溜りが存在する 実鈎系の概略図である．管路は銅管からなり，内径D $=17.05 \mathrm{~m}$ ，全長 $24.7 \mathrm{~m}$ である. 管路上流端には約 $12 \mathrm{~m}$ の高さに設置されている内容䆏 4 m’のオーハーフロータ ンク®があり，てのタンクから直線并(2までは水が渾 たされており，直線并から下流端の絞り抵抗部(3)(お ろいは閉端）までが空気濑りとなっている．設置した 直線弁は全開時に管内径亡同一径となるように䌘作し てあり，直線弁の開放操作は油圧シリンダーを用いて 行い, 弁の開放所要時間は0.09秒程度であった.また, 较り抵抗部の口径 $\mathrm{d}$ は14.7, 13.1,11.3,9.1,6.8 m m 5 種 類である. 圧力応答波形は絞り部直前位圈に取付けた 半導体式圧力变換器(4)で測定し，增幅器(5)を通して電 磁オシロクラプで記録した。

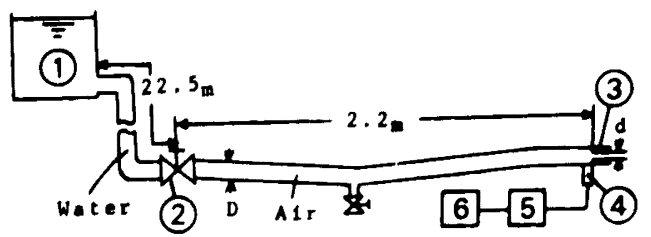

Fig. 2 Experimental setup of liquid system with air pocket

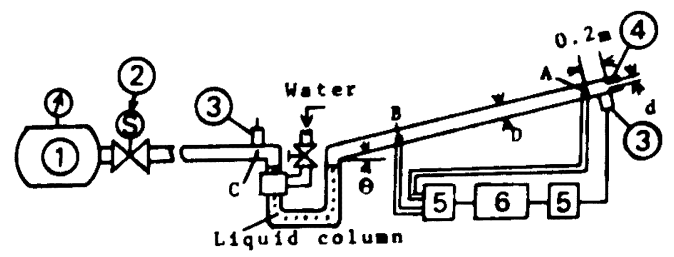

Fig. 3 Experimental setup of air system with liquid column

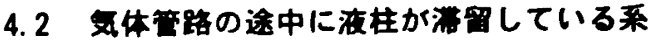

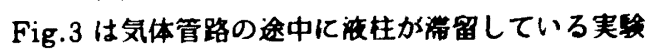
系の概略困である，管路には 2 重頪の管内径 $(\mathrm{D}=7$. $525,17.05 \mathrm{~m}$ ）をすつ铜管を使用し， $\mathrm{D}=7.525 \mathrm{~m} ， \mathrm{~m}=$

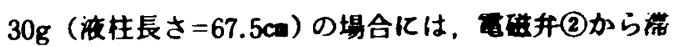
留洨柱の上流端まで約 $2.25 \mathrm{~m}$ ，洼柱の下海端から较り 抵抗部まで $1.55 \mathrm{~m}$ である。.また，各管路の下流端に設 园した较り部の口径dは，Table1に示すように5面 り変化させ，実稌は次のようにして行った。ます，眍

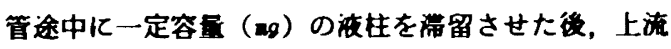
端にある西碰并(2)を操作するととにより内容稍約 100

\begin{tabular}{|c|c|c|}
\hline & $\mathrm{D}=7.525_{\mathrm{mm}}$ & $\mathrm{D}=17.05_{\mathrm{mm}}$ \\
\hline d & $\begin{array}{l}6.5 \mathrm{~mm} \\
5.8 \mathrm{~mm} \\
5.0 \mathrm{~mm} \\
4.0 \mathrm{~mm} \\
3.0 \mathrm{~mm}\end{array}$ & $\begin{array}{r}14.7 \mathrm{~mm} \\
13.1 \mathrm{~mm} \\
11.3 \mathrm{~mm} \\
9.1 \mathrm{~mm} \\
6.8 \mathrm{~mm}\end{array}$ \\
\hline$L_{0}$ & $12.0 \mathrm{~mm}$ & $26.4 \mathrm{~mm}$ \\
\hline & 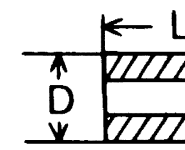 & ${ }_{Z{ }^{2}}{ }^{\mathrm{x}} \mathrm{d}$ \\
\hline
\end{tabular}

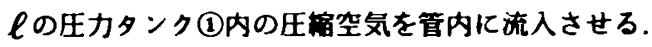

Table 1 Dimensions of orifice 
これにより洨柱が移助し、下流端の校り抗部(に道 する祭に生じた圧力底答波形は，Fig.3のC点（磷 并からの野 $2 \mathrm{~m}$ ）および校り部遖前位目に取付けた

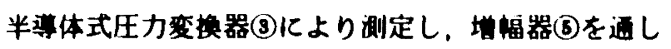

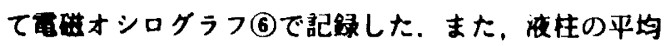

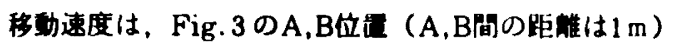

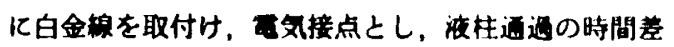
を電磁オシログラフで記䟿したデータから硓みとり測 定した. Fig.4は2厓類の供武管路において供給庄P. 校り口徍dを㚆化させて得た校り部直前位目における 代力応答波形の記绿例を示し， $\overline{\mathrm{V}}_{w}$ は佊柱の平均移斩 速度であろ。

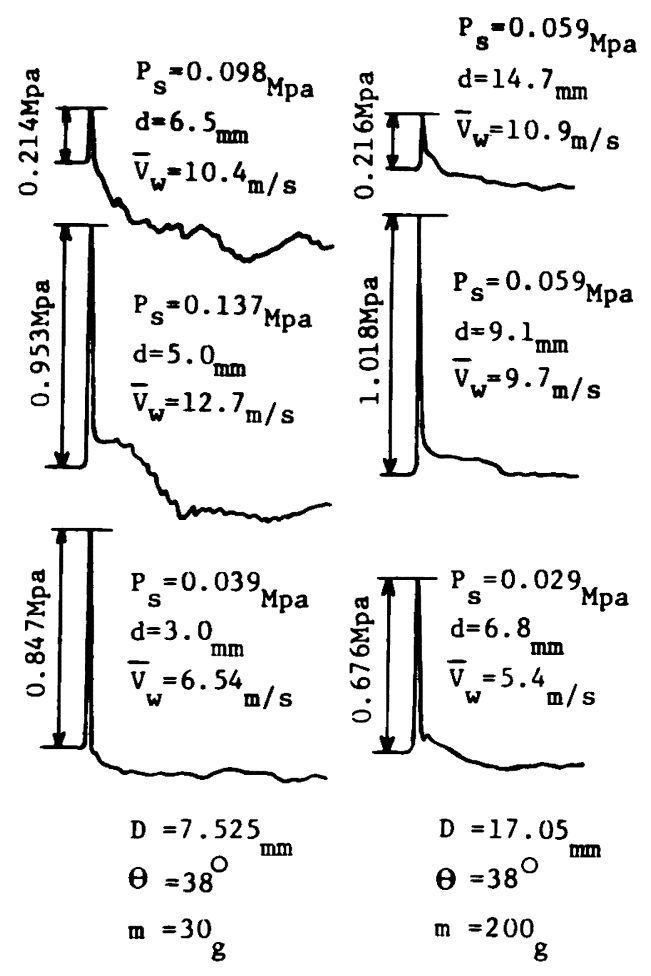

Fig. 4 Traces of pressure response

\section{3 校り部の流量係数 $\mathrm{C}_{\mathrm{a}}, \mathrm{C}_{\mathrm{w}}$ の実测}

式(4)により最大圧力上昇値を計算するためには，気 体および液体通過時における较り抵抗部の流量係数 $\mathrm{C}_{a}, \mathrm{C}_{w}$ を求めておく必要がある， $\mathrm{C}_{\mathrm{a}}, \mathrm{C}_{\mathrm{w}}$ の值は，较 り抵抗部の形状とレイノルズ数 $\mathrm{R}_{\mathrm{E}}$ とにより決まるた め、つぎのように実鈎により測定した。 まず，空気通 過時の流量係数 $\mathrm{C}$ 在求める実呀にはFig. 3の管路系, ま た，水通過時の流量係数 $\mathrm{C}$ 、を求める実䂆には Fig. 2 の管路系を用いて流れのレイノイズ数 $\mathrm{R}_{\mathrm{E}}\left(\mathrm{R}_{\mathrm{E}}=\mathrm{VD} /\right.$

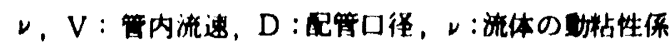
数）を安化させ，校り部古前位泪に取付けたビト一管

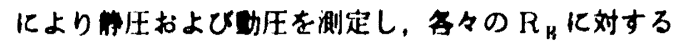

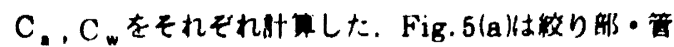

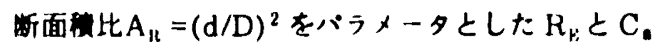
との保因，Fig.5(b)は同㥞に $A_{R}$ をバラメータとし

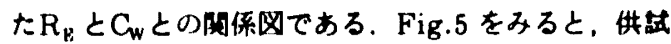
较り抵抗部の流目係数はオリフィス型というよりフロ 一ノズル型䎲近い值となっており，使用した校り抵抗 部はフローノスルに近い型の絞りに凨すると思われる。

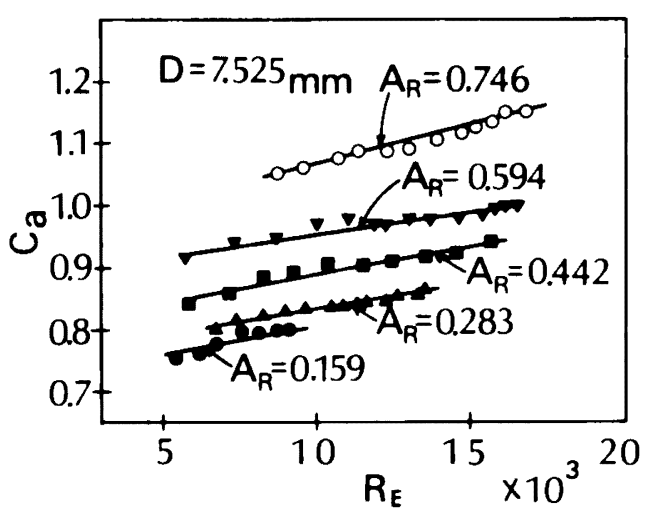

Fig. 5 (a) Relations between $R_{E}$ and $C_{a}$

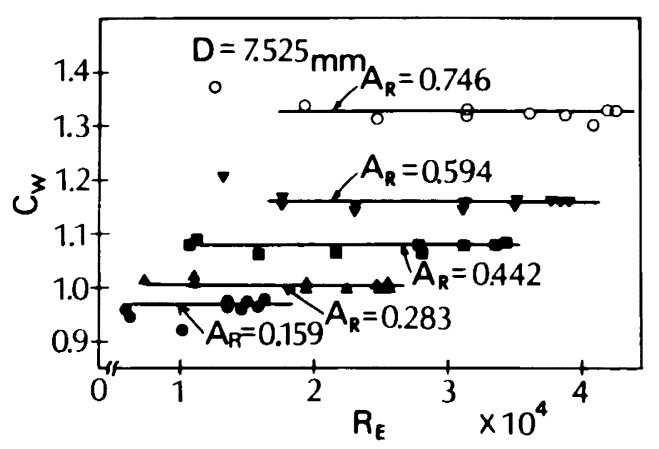

Fig. 5 (b) Relations between $R_{E}$ and $C_{w}$

\section{5. 結果亡考察}

\section{1 液体管路の下流位置に空気溜りがある系}

Fig.6は，Fig.2の下流端が閉端となっている密閉 系での応答波形であり，液柱の速度 $V_{w}$, 空気溜りの 容積 $\forall$, 空気溜り内の圧力 $P_{d}$ の理論新算結果をそれ ぞれ実線で示し，破線が実験で得られた圧力応答波形 である. 理論計算は式(5),(6)，(7)を用い，4次のルンゲ 
クッタギル法により行ったか，密閉系を对银としてい ろので式(7)のG。 $0=0$ とおき，また式(5)の $\theta=0$ とおき， $\Delta \mathrm{t}=0.01$ 秒どとに数值胡聚を行った結果を示す. Fig. 6 の䊅果は, Streeterら”およびMartin”によろ富

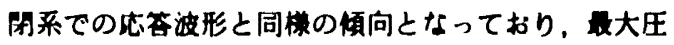
力上界檤は供給圧の約 2.4 倍程度であり，空気诲りか ない系の堨合より大きいことがかる。（空気济りか ない系での压大力上年攸は供給圧の 1.8 倍程度であ उ").)

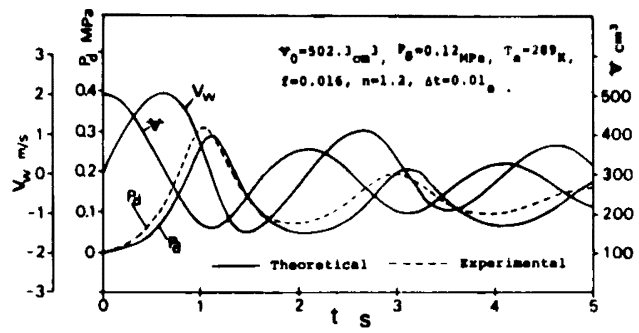

Fig. 6 Transients for confined system

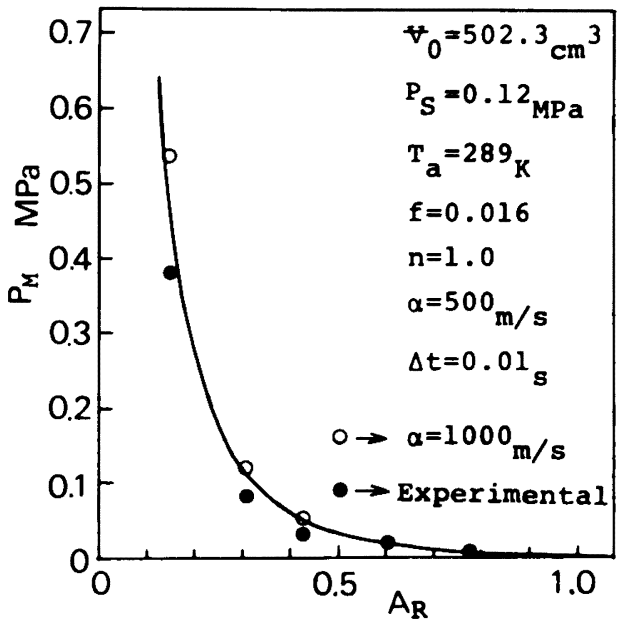

Fig. 7 Comparison of the results for open system

つぎにFig.2の下流端が絞り抵抗部となっている開 放系の場合を対象とし，液柱が絞り部に衙突する際の 最大任力上昇値の理論計算結果（実線で示す）之実雅 結果（黒丸印）とを比较した図がFig.7である。理論 計算には密閉系の場合と同様にまず式(5),(6),(7)を用い 4 次のルンゲクッタギル法により過渡計算を行い，液 柱が絞り部に達する直前の時刻における空気溜り内の

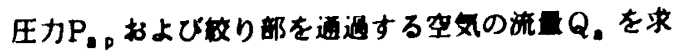
めた，その役てれらの得を用いて式(4)により原大力

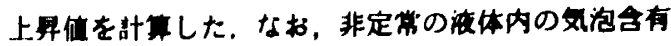

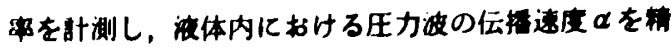

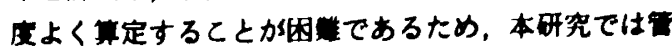

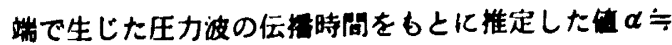

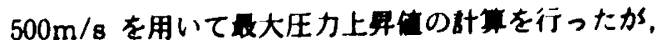
$\alpha=1000 \mathrm{~m} / \mathrm{s}$ として叶萣した結果（白丸印）を比位の 意味でFig.7 亿示す. $\alpha=1000 \mathrm{~m} / \mathrm{s}$ とし得られた結果 は $\alpha=500 \mathrm{~m} / \mathrm{s}$ の场合の結果より少し高い值となった が差はあまりなかった。またFig.7をみると、较り郡 ・管断面碳比 $A_{R}$ が小さくなるにつれて生ずるサーシ 圧力は指数网数的借加しており，本供試管路采ては $\mathrm{A}_{\mathrm{R}}<0.2$ になると密闌系の场合より 大きなサージ圧 力が発生した。 また，Fig.6，Fig.7 より実错值と理 論値はかなりよく一致しており，集中定数近似して かれた基磁式を用いた計算法を採用しても現象をかな りよくとらえることかできるすのと弗えられる。

つぎにFig.8 は供給圧 P.をバラメータとした $\mathrm{A}_{\mathrm{R}}$ と最大圧力上昇値 $\mathrm{P}_{\mathrm{M}}$ との関係园であり。乙の图はFig. 2 の供試管路系において仮に供粭圧のみを変化させて 考え理詥計算し得た結果を示す．Fig.8よりP，が高 くなるにつれて $P_{N}$ あ大きくなっているてとかかかる. この理由としては， $P_{8}$ が高いはど $P_{a p}$ が大きくなり， また Q 、はPapに比例すると考えられるから， $P_{M}$ の計算式(4)での $\mathrm{B}=\alpha \rho_{w} Q_{a} / 2 \mathrm{aP}$ ap の值はかえって䖵 少し，てれにより $\mathrm{P}_{\mathrm{N}}$ が大くなるるのと考えるとと ができる.

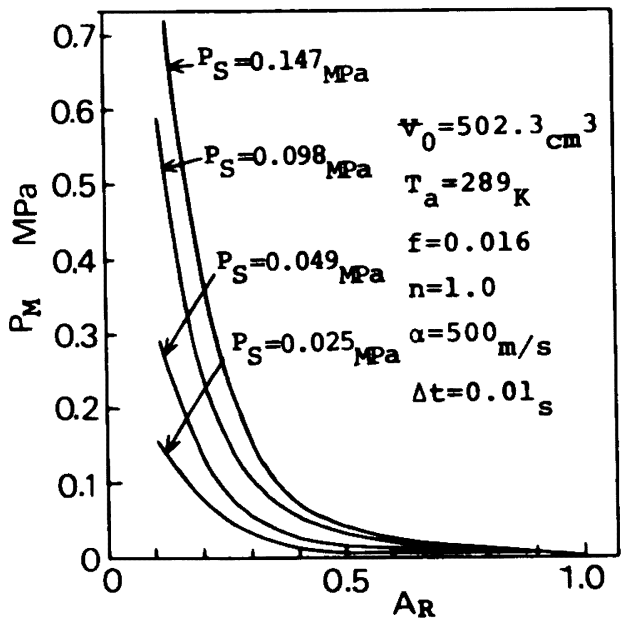

Fig. 8 Effect of $P_{S}$ and $A_{R}$ on $P_{M}$ 


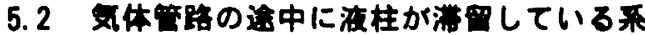

Fig.9は，筊り抵沉部・管断面模比 $A_{\mathrm{R}}$ をバラメー 夕とした液柱の平均移较速度 $\overline{\mathrm{V}}_{\mathrm{W}}$ と樶大压力上界值 $\mathrm{P}_{\mathrm{N}}$ との成係图であり，Fig.3の供式系において $\mathrm{D}=$ $7.525 \mathrm{~mm}$ の管を使用して得た実倹結果を示す．Fig. 9より $A_{R}$ が小さくなり，かっ $\bar{V}_{W}$ が速くなるはど大き なサージ氏カが発生するととがかかる。つぎに Fig.10 は， $A_{R}$ が檑端に小さくなった埸合任生ずるサージ仕 カがどのようになるかを調へろために，口径が小さな 校りを特に多く用意して $\mathrm{D}=17.05 \mathrm{~m}$ の管により実矣 した桔果をるとに作成した図であり， $\overline{\mathrm{V}}_{\mathbf{W}}$ をパラメー

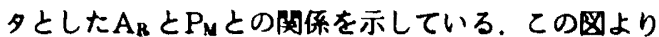
$\mathrm{P}_{\mathrm{N}}$ は $\mathrm{A}_{\mathrm{R}} \fallingdotseq 0.09$ で取大となり， $\mathrm{A}_{\mathrm{R}}<0.09$ になるとそ れを境にしてP只が小さなってくるてとがわかる。

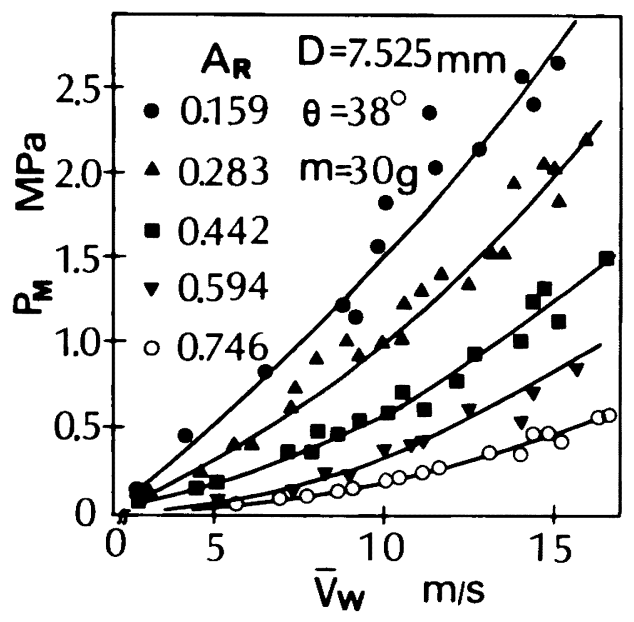

Fig. 9 Effect of $A_{R}$ and $\bar{V}_{w}$ on $P_{M}$

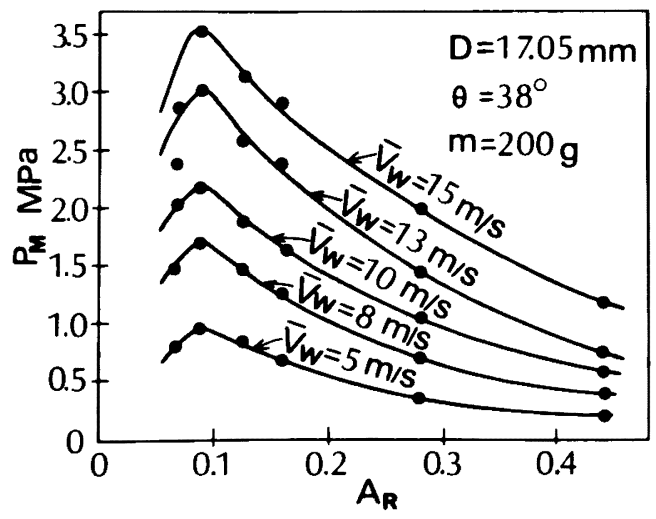

Fig.10 Effect of $\bar{V}_{W}$ and $A_{R}$ on $P_{M}$

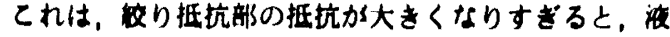

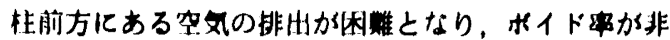
常に大きな2 相流の状態で波が流出するととによるも のと思われる。

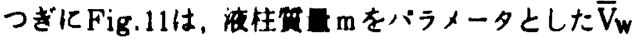

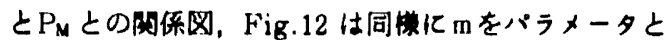
した供給圧 $P 、 と \bar{V}_{w}$ の関係図であり，いずれも $D=17$. $05 \mathrm{~mm}, d=9.1 \mathrm{~mm}$ の眍管を用いて得られた実就結果を示 す. Fig.11より同一の $\bar{V}_{\mathbf{w}}$ の仵䎲対しては，m汃大き いほど生ずるサージ压力が大きくなっているてとがわ かる．との理由はFig.12をもとに考察できる。すすな ち、 $\overline{\mathrm{V}}_{\mathrm{w}}$ を同一にするためにはmが大きいほど高い供 給圧か必要となることがFig.12よりわかる.したがっ て，mが大きいはどP。汃大きくなり，Fig.8で説明

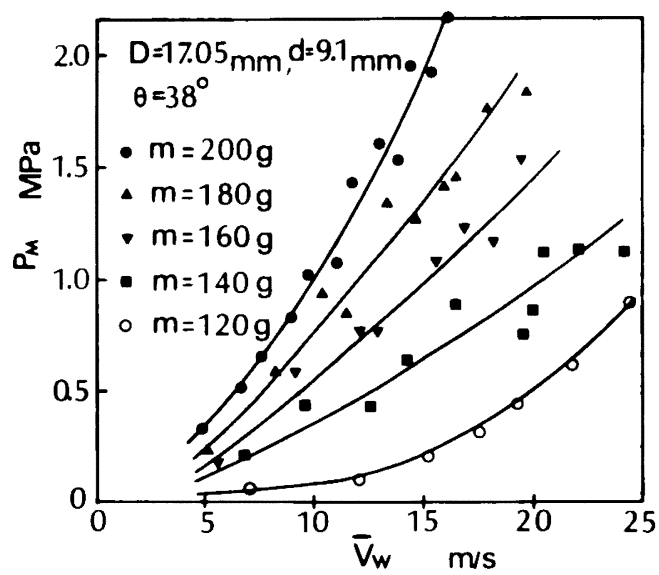

Fig.11 Effect of $m$ and $\bar{V}_{w}$ on $P_{M}$

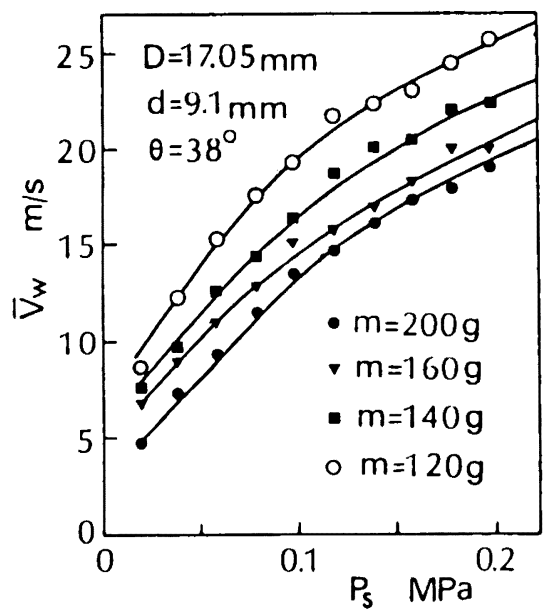

Fig.12 Effect of $m$ and $P_{s}$ on $\bar{V}_{w}$ 
したのと同籾の理由で生ずるサージ任力が埥大するす のと考えられる。

つぎにFig.13は, $D=17.05 \mathrm{~mm}, d=9.1 \mathrm{~mm}, m=200 \mathrm{~g} の$ 条件下での管傾斜角 $\theta$ をバラメータとした $\mathrm{P} 、 と \mathrm{P}_{\mathrm{M}}$ の

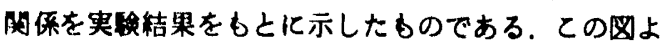

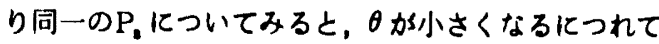
生ずるサージ圧力が大きくっているととがわかる。

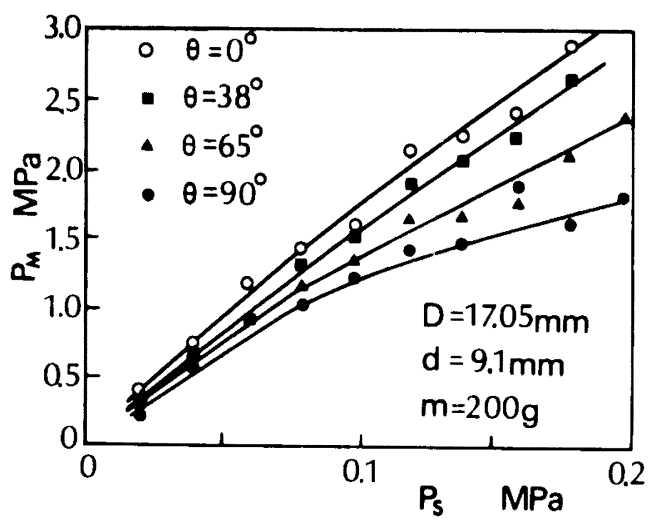

Fig.13 Effect of $\theta$ and $P_{S}$ on $P_{M}$

この理由を半実稌的に考察するために，Fig.3の C 点 と交り直前位霬での圧力の過渡変化の測定結果をると に式(5)の $\mathrm{P}_{\mathrm{u}}, \mathrm{P}_{\mathrm{d}}$ ，すなわち，液柱の上流側および流 側圧力を推測したところ，液柱が校り部達する直前 までの過程において $P_{\mathrm{u}} \fallingdotseq \mathrm{P}_{\mathrm{s}}$ であり，また $\mathrm{P}_{\mathrm{d}}$ は $\mathrm{P}_{\mathrm{u}}$ に 比して非常に小さく $P_{d} \ll P_{u}$ とみなしてさしつかえな いととがわかった。したがって，近似的に式(5)のみを 考虑し，液柱の移動速度の計算式を求めると， $\mathrm{V}_{\mathrm{w}}=$ $\mathrm{V}_{\mathrm{wo}}+\mathrm{C} \triangle \mathrm{t} . . .(8)$ となる. ことで, $\mathrm{V}_{\mathrm{w} o}=\Delta \mathrm{t}$ 時間前の 液柱の移動速度, $\mathrm{C}=\left(\mathrm{AP}_{\mathrm{a}}-\mathrm{F}_{\mathrm{e}}\right) / \mathrm{m}-\mathrm{g} \sin \theta$ である。 液柱による動摩擦力 $\mathrm{F}_{\mathrm{e}}$ および液柱質量血を一定とする と, 式(8)でのCは $\theta$ が小さくなるはど大きい，てのた め, 液柱が絞りに達する際の速度は $\theta$ が小さくなるに つれて速くなり，生ずるサージ圧力が大きくなるもの と考えられる。

つぎにFig.14は, $\mathrm{D}=7.525 \mathrm{~mm}, \mathrm{~m}=30 \mathrm{~g}, \theta=38^{\circ}$ の条 件下での $\mathrm{P}_{\mathrm{M}}$ の計算結果（破線で示す）と実矣結果（実 線）との比較図であり， $A_{R}$ をパラメータとした $\mathrm{P}$, と $\mathrm{P}_{M}$ の関係を示す. $\mathrm{P}_{\mathrm{M}}$ の理論值を求めるに際しては, Fig.2の系の場合と同様にまず式(5),(6), (7)を用い， 4 次のルンゲクッタギル法を使用して $\triangle \mathrm{t}=0.01$ 秒ごとに $\forall, V_{w}, P_{d}$ の過渡計算を行い, $t=t_{c}$ での $P_{a p}$ お よび $\mathrm{Q}$ a を求めた後, 最大圧力上昇值の計算式(4)を用
いてP $\mathrm{M}$ を計算した。なお，ボリローブ指数 $n=1.0$ ， 体内の圧力波の位揞速度 $\alpha=500 \mathrm{~m} / \mathrm{s}$ とした。

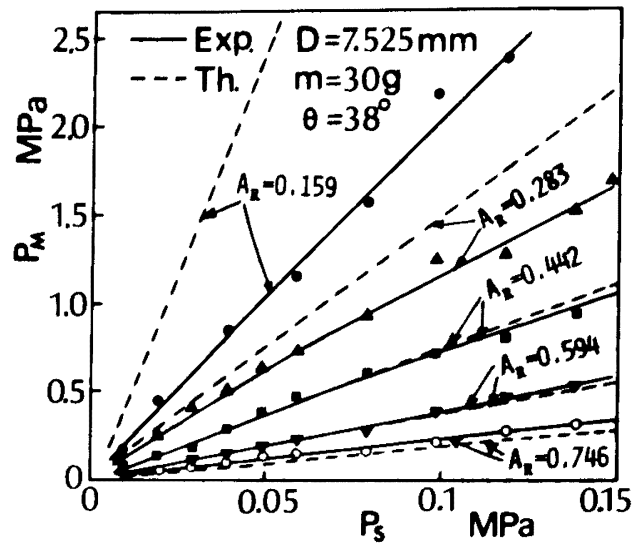

Fig. 14 Comparison between experimental and theoretical results

Fig.14より， $A_{R}$ が大きい場合には計算結果と実鈋结 果とはよく一致しているか， $A_{\mathrm{R}}$ が小さくなるにつれ て差が生じ，計算値の方がかなり大きな值となってく るととがわかる. ての理由としては，(1). 制り部の抵 抗が大きくなるはど游柱前方にある空気が排出されに くくなり，管内に残留する空気醘が多くなる。乙のた め， $\mathrm{A}_{\mathrm{R}}$ が小さくなるにつれてボイト军が大きい状態 での液の流出が生ずる。 (2). したがって，较り部から の流体の流出が気体から波体人之賍間的化変化する のとして筫出された最大圧力上昇值の計算式(4)による 計算結果は， $\mathrm{A}_{\mathrm{R}}$ が小さくなるはど実段結果よりかな り大きな值となるなどが考えられる。しかしながら， 実際的な見地加考えると，採用した近似計算法は実 際に生ずるサージ圧力の予知に有勃であると考えられ ろ.

\section{6. 結 言}

液体管路内に空気溜りが存在する系および気体管路 内に液柱が滞留している系を統一的に取扱い，上流 の并の急開化伴い生ずる過渡的圧力応答の問題につい て実験および理論計算を行い，考察し得られた主な点 は次の如くである．まず前者の系においては，(1)密閉 系，開放系での理論計算結果は実験結果とかなりの程 度まで一致した。(2)密閉系の場合より $\mathrm{A}_{\mathrm{R}}$ が小さい開 放系の場合の方が大きなサージ圧力が発生する可能性 がある.つぎに後者の系においては，(2) $\mathrm{A}_{\mathrm{R}}$ が小さく なるほどサージ圧力は增加するが, $A_{R} \fallingdotseq 0.09$ になる とそれを境にサージ圧力は減少する。(4) $\overline{\mathrm{V}}_{\mathrm{w}}$ が同じで 
あれば， mが大きいはどサージ圧力は塔加する、また，

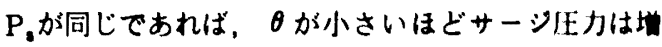
加する. (5) $\mathrm{A}_{\mathrm{R}}$ が小さくなると管内に残留する空気

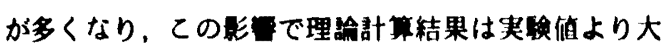
きな値となる。

以上の結果が得られたが，本研究で采用した近似竍 算法は，実除的な見地からみれば，空気海りおよび流

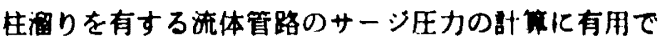
あると思われる。

最後に本研究に対して車重な御助言をいただいた京 都大学花房秀郎教授に深く㵊意を表します。

1) 星ほか 2 名：半閉の茾を有するポンプ系の起轩時 の水䨣，機論，66-531，93/45 (1963).

2) V.L.Streeter, E.B.Wylie: Hydraulic Transients, 218, Mcgraw-Hill (1967), 同 竹中監訳：流体過渡現象，250，日本工業新聞社 (1973).

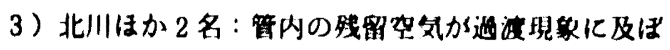

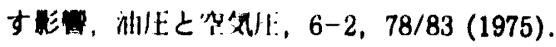

4) C.S.Martin: Entrapped Air in Pipelines, Second International Conference on Pressure Surges, 15/23 (1976).

5）北川：波体䇺路队サージ圧力の一根和法，機检， 44-383，2352/2362 (1978).

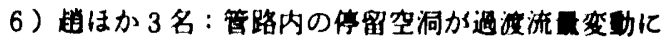
及ばす影機㫻，50-460，3116/3123 (1984).

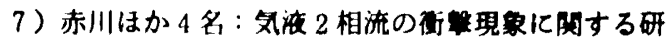

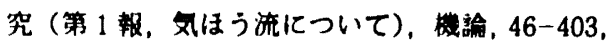
$492 / 500$ (1980).

8）赤川はか 4 名: 気流 2 相流の街現象に関する研 究（第 2 報，スラグ流について)，機論，47-419， $1287 / 1297$ (1981).

9）橋本ほか 2 名：特性格子法仁基つくく流体管路の過 渡応答の解析, 油圧之空気圧, 16-2,70/76 (1985). 